\title{
MICROBIAL AND PHYSICO-CHEMICAL ASSESSMENT OF WASTEWATER PLANTS BEFORE DISCHARGE IN QARUN LAKE, EL-FAYOUM GOVERNORATE, EGYPT.
}

\author{
Mahmoud M. El-sayed ${ }^{1}$, Ahmed Darwish El-Gamal ${ }^{1}$, Amr Fouda* ${ }^{1}$, Ahmed A. \\ Radwan $^{1}$ \\ ${ }^{1}$ Department of Botany and Microbiology, Faculty of Science, Al-Azhar University \\ *Corresponding author: Amr_fh83@azhar.edu.eg
}

\begin{abstract}
This study is performed on six wastewater stations that discharging wastewater into Qarun lake, El-Fayoum Govenorate, Egypt, to assessment wastewater treatment on the period from April 2017 to February 2019. Sewage treatment plants use different biological treatment technologies (conventional activated sludge, oxidation ditch, aeration). In this investigation, wastewater samples were collected from the influent and effluent of each plant and transferred directly to central laboratory of Fayoum Wastewater Company for complete analysis. The obtained data reflects a large amount of drainage on the wastewater treatment stations which means high percentages of total coliform and fecal coliform. Also, the high algal content is detected at Tamiya station with total cell count $282-1210 / \mathrm{L}$. Nutrients as nitrate, nitrite, ammonia and phosphate are assessed and exhibit in ranges 4.4-104.5, 0.0-8.0, 1.1-43.0 and 1.0-42.1 mg/L, respectively. On other hand, the increase of TDS and TSS were achieved during summer season. Furthermore, higher values of DO, BOD and COD considered as a strong indicator for higher microbial activity.
\end{abstract}

Keyword : wastewater treatment; biological treatment; Qaroun Lake; algal content; bacterial count 


\section{INTRODUCTION}

In recent years, Egypt has suffered from severe water scarcity. Water per capita has fallen significantly to less than $1000 \mathrm{~m}^{3} / \mathrm{year}$, which is known as the "Water Poverty Mark" and was expected to decrease to $500 \mathrm{~m}^{3} /$ year by 2025 (Abdel Wahaab, 2003). The new Egyptian water budget indicates that the annual water demand reaches $6 \mathrm{gm}^{3} /$ year of the available fresh water. Meanwhile, the demand for water is increasingly growing due to population growth, industrial usage and an increase in living standards.

Deterioration of water quality is one of the major factors that are playing havoc with water safety and public health of Egypt. The decreasing quality of water has become a global concern as human population increases, industrial and agricultural activities expand and potential climate change may threaten the hydrological cycle (WWAP, 2009). Poor water quality has a direct impact on the quantity of water in several ways: polluted water that cannot be used for drinking, bathing, industry or agriculture effectively reduces the quantity of usable water within a given area. In general, the water crisis appears to be seen as an issue in terms of water quantities; however, water quality is recorded as a major factor in many countries (Abdel Wahed et al., 2014).

The contribution of polluted water to the water crisis has also been calculated in recent years in the loss of beneficial use: that is, water lost for beneficial human, agricultural, and ecological uses through excessive contamination by bacteria, nutrients, metals, organic matter, salinity, and other toxic waste (Fathi and Flower, 2005). Poor water quality had already largely been linked to public health concerns through waterborne disease transmission. This is a well-known issue in Africa and many other developing countries (Abdel Kawy and Belal, 2012).

The River Nile is Egypt's lifeline as it serves the industrial and agricultural demand of the country, and is the population's primary source of drinking water. Due to the critical water insufficiency situation in Egypt, water quality monitoring of the Nile River is essential to maximize the use of every drop of water (FAO, 2003). Fayoum, meaning "the Sea" (Fathi and Flower, 2005), and its catchment has a unique character, even though it is regarded an oasis, it is fed by Nile water that flows into the El-Fayoum depression via the Bahr Yousef waterway. El-Fayoum is a closed basin in an arid zone with an inner drainage resulting in no outflow of water except by evaporation (Abdel Kawy and Belal, 2012). This ensures that all dissolved constituents will remain either in the water or in the sediments and will accumulate in depression. In the El-Fayoum region, the irrigation and agricultural system depends on this water. The secondary source of irrigation water at El-Fayoum, however, is the reuse of drainage water due to water scarcity. Drainage water reuse in agriculture has some general limitations due to the potentially high (semi-) metal and pathogen content (Mansour and Sidky 2002, 2003). Due to this extensive irrigation by lowquality water as well as inadequate sanitation arrangements, waterborne diseases are thus a particular concern in the El-Fayoum Governorate. It is an indicator that the water quality has a significant effect not just on the quantity of water but also on human health. 
Therefore, in this study, the assessment of influent and effluent wastewater of six station at El-Fayoum Governorate namely Atsa, Old Qahfa, New Qahfa, Tamiya, Snores and Tatoun were investigated before discharge their content into Qarun lake.

\section{MATERIAL AND METHODS}

\section{Case of study and samples}

This study is aimed to evaluate the performance and efficiency of the wastewater treatment plants in El-Fayoum Governorate, Egypt. Sampling and preservation procedures are carried out in accordance with American Public Health Association "Standard Methods for the Examination of Water and Wastewater" (APHA, 2005).

Sampling occurred by using automatic sampler, which collected one sample every two hours a day in a two liter non-sterilized glass bottle to form a composite sample. Then the samples were transferred to the laboratory and inspected within one hour of collection. For the entire duration of the analysis, the samples were kept constantly homogenized and aerated to hold all the solids in suspension.

Samples were collected seasonally manually in sterile, $500 \mathrm{~mL}$ non-reactive borosilicate glass or plastic bottles for microbiological examinations. All samples were stored at $4^{\circ} \mathrm{C}$ in a refrigerator, until microbial experiments were used.

Survey of the present study covers the investigation of six stations of the Fayoum Governorate namely Atsa, Old Qahfa, New Qahfa, Tamiya, Snores and Tatoun Stations, as shown in Figure 1.

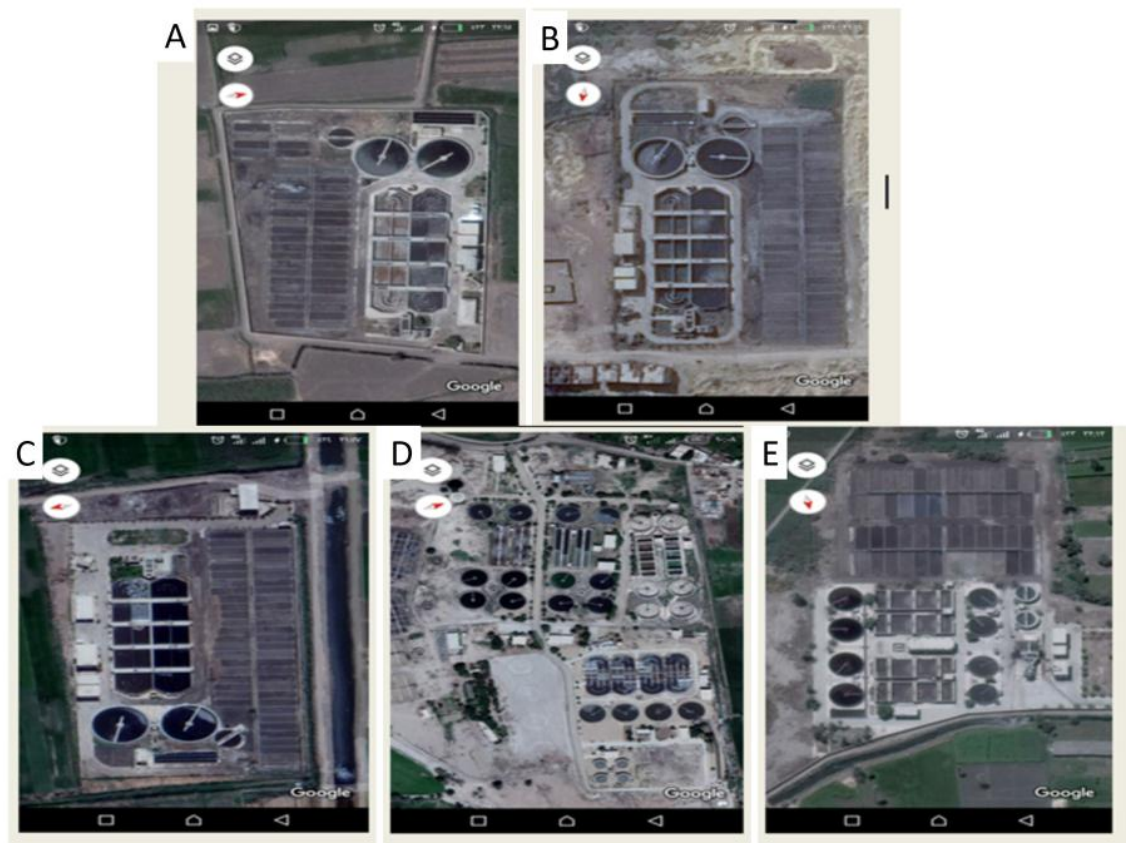

Figure 1 : Google map for six wastewater stations in El-Fayoum Governorate which used in this study, A, atsa stations; B, tatoun stations; C, senores stations; D, tamyia stations; E, new and old Qahfa station. 


\section{Sampling process}

The wastewater treatment plant in El-Fayoum Governorate operates use different biological treatment technologies (conventional activated sludge, oxidation ditch, aeration), where the raw sewage is collected in the (influent) inlet chamber. Forward to screening and grit removal, the wastewater is collected in aeration tanks in which mechanical aeration (surface aerators) is used to achieve the aerobic environment.

The mixture is passed into second sedimentation tanks after a specified time period, where the sludge is separated from the treated wastewater. The portion of the activated sludge is recycled to keep the desired organism concentration in the aeration tanks. The wastewater obtained from the secondary sedimentation tanks is then disinfected in chlorine chambers by chlorination, and the effluent can be reused in agriculture after chlorination.

Using three auto samplers, the samples were taken from three sites representing the principal different stages in the wastewater plant. Samples were obtained from prominent (raw sewage), second sedimentation tank outlet (after biological treatment) and chlorination outlet (effluent).

\section{Microbial analysis (Estimation of Total Coliforms (TC) and Fecal Coliforms (FC))}

The number of total coliforms and fecal coliforms was determined using the most probable number (MPN) technique; three dilutions of each sample were used, three replicates of MacConkey broth media containing $(\mathrm{g} / \mathrm{L})$ : peptone, $20.0 ; \mathrm{NaCl}$, 5.0; lactose, 5.0; sodium taurocholate, 5.0; bromocresole purple, 0.01 and $\mathrm{pH}$ adjusted to 7. Double and single strengths for $10,1.0$ and $0.1 \mathrm{~mL}$ were used, respectively. All tubes were supplied with Durham fermentation tubes. Inoculated tubes were incubated at $35 \pm 0.5{ }^{\circ} \mathrm{C}$ for 48 hours and at $44.5{ }^{\circ} \mathrm{C}$ (in a water bath) for 24 hours for fecal coliforms. The formation of acid and gas is a positive result. Positive tubes were streaked onto the Eosin Methylene Blue (EMB) agar plates using a sterile loop and incubated at $37{ }^{\circ} \mathrm{C}$ for 24 hours and a microscopic test was performed as a confirmatory test.

\section{Physical and chemical analyses}

Water temperature $\left({ }^{\circ} \mathrm{C}\right)$ and $\mathrm{pH}$ were measured using Hydrolab model Multi Set 430i WTW.

Dissolved oxygen was measured using the modified Winkler method and biochemical oxygen demand with the five-day incubation method (APHA, 1998). Chemical oxygen demand was carried out using the potassium permanganate method (Golterman, 1981).

Total solids were measured by evaporating a known volume of well mixed sample. A total dissolved solid was determined by filtering a volume of sample through a glass fiber filter (GF/C), and a known volume of filtrate was evaporated at $105^{\circ} \mathrm{C}$. Total suspended solids equal the difference between TS and TDS. 
Colorimetric methods were used to determine ammonia, nitrite (APHA, 1998) and nitrate as well as total phosphorus (mg/l) (APHA, 1998).

Turbidmetric method is used for sulphate estimation (S, mg/L) (Liu, T.; Wang, H.; Yang, H.; Ma, Y. and Cai, O. (2009). Heavy metals (Fe, $\mathrm{Zn}, \mathrm{Cu}$, and $\mathrm{Cr}$ ) were measured as (mg/l) using atomic absorption on AA spectrometer (Solaar 969) after digestion by Nitric acid (APHA, 1998).

\section{STATISTICAL ANALYSIS}

Data were statistically analyzed using analysis of variance (ANOVA) using the STATISTICA (6.0) computer programs.

\section{RESULT AND DISCUSSION}

\section{Microbial characteristics}

Microbial assessments at El-Fayoum different wastewater plants are mention at (Figure 2). The bacteriological quality of water was generally controlled by certain parameters as bacterial density in terms of plate count at $22^{\circ} \mathrm{C}$ and $37^{\circ} \mathrm{C}$ and coliforms as indicator of fecal pollution (Noble et al., 2004).

Coliforms have been internationally recognized for the evaluation of the microbiological content of water. Total coliform and fecal coliform were calculated using the most probable number (MPN) technique. Numbers of TC at El-Fayoum different stations were in the range of 600- 17000 in Tamiya and Snores stations, respectively.

Numbers of fecal coliforms (FC) were in the range of 200-1000 at the Oldest Qahfa, Atsa as well as Tamyia and the Newest Qahfa, respectively.

This could be clarified by the impact of the discharge of domestic and agricultural waste from urbanized surrounding areas (Sabae and Rabeh, 2007).

High FC values may be attributed to the effect of wastewater. The results obtained indicate that high numbers of TCs have been recorded at stations opposite to El-Batts and El-Wadi drains. This may be due to the impact of drainage and human activities and the impact of contamination on bacterial interaction (Edberg $\boldsymbol{e t}$ al., 2000). 


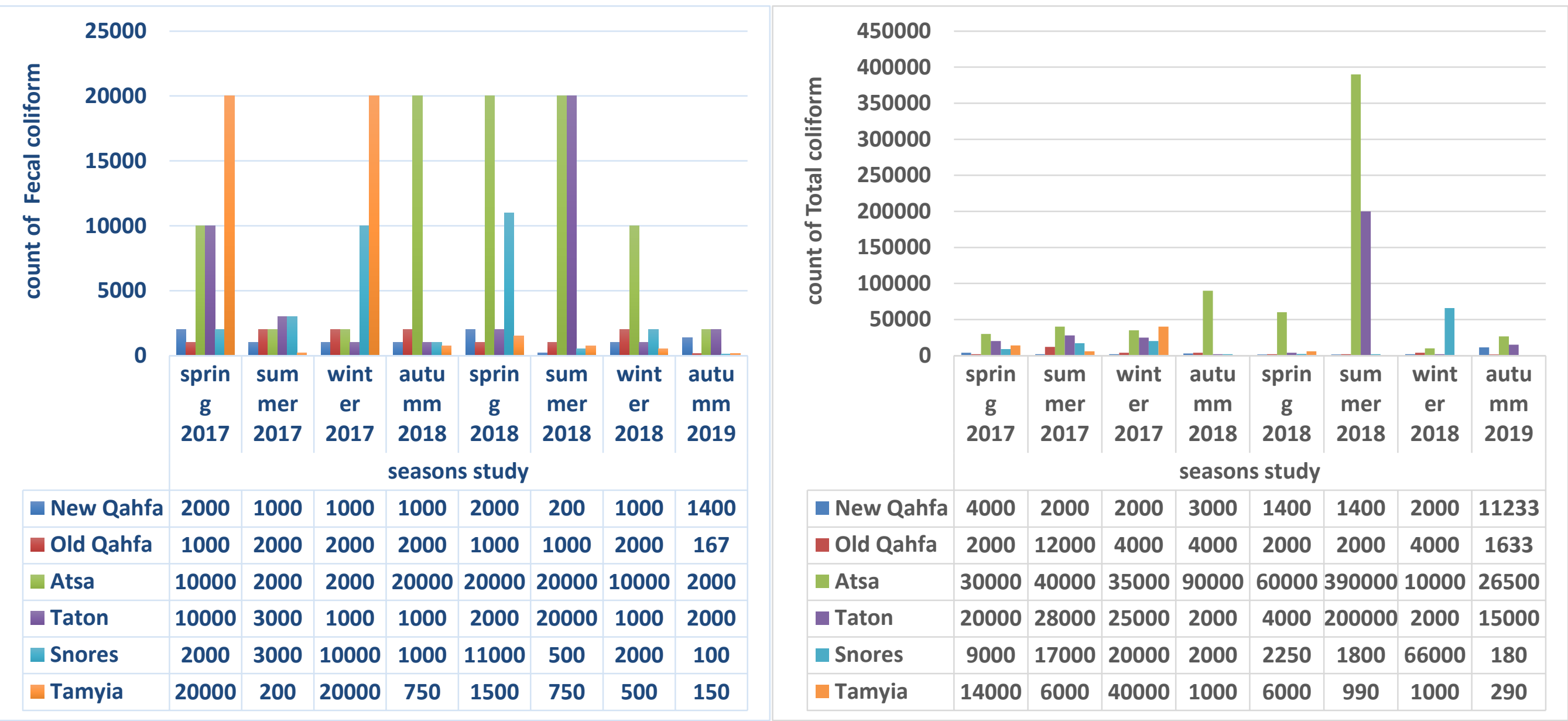

Figure 2: Fecal coliform (FC, 2000Ml) and Total coliform (TC, CFU/5000mL) in six wastewater stations during spring 2017 to winter 2019 . All data represents means of five replicates \pm SD. 


\section{Algal contents}

Algae have historically been seen as a problem for wastewater treatment. Unicellular microalgae can be difficult and costly to remove and failing to adequately do so can cause problems downstream or lead to the creation of dangerous disinfection byproducts (DBPs) (Coral et al. 2013, Nguyen et al. 2005, Vuuren and Duuren 1965). Although algae have negative impacts on water treatment processes, but it can be used to treat wastewater and improve wastewater treatment plant effluent through generating biomass that could be used to produce biofuels (Schumacher et al. 2003, Wang et al. 2010, Sturm et al. 2012, Arbib et al. 2014, Park et al. 2011, Pittman et al. 2011).

In this study, algal content in Atsa, Old Qahfa, New Qahfa, Tamiya, Snores and Tatoun stations were found in the ranges of (410- 890), (378-1122), (322-940), (2821210), (188-986) and (433-766) C/1, respectively, as shown in Fig. (2).

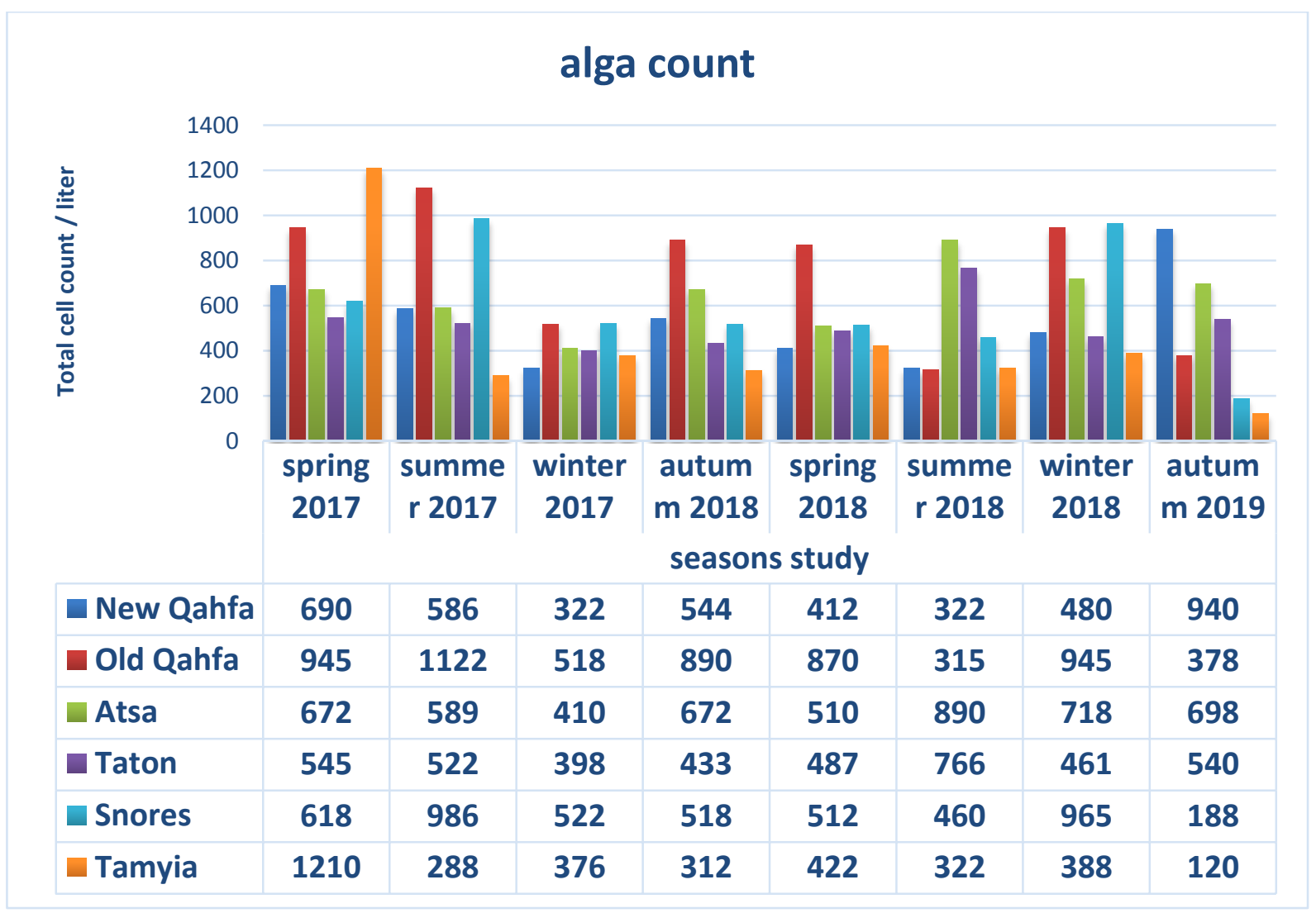

Figure 2: count of alga in six wastewater stations during spring 2017 to winter 2019.

\section{Chemical and physical analysis.}

\section{A. Temperature}

The temperature results during the study period were consistent with the provisions of Law No. 48 of 1948 regarding the protection of the Nile River and its 
implementing regulations for the drainage of treated wastewater into water environments. Where they were allowed to determine the degree of temperature $15-35^{\circ}$ C.

The water temperature of the different stations showed an increase during summer season and was found to be range between (32-31) ${ }^{\circ} \mathrm{C}$ thought the summer in 2017 and 2018 with no significant difference between the stations, and the lowest temperature recorded was $17.30{ }^{\circ} \mathrm{C}$ during winter season of the year 2018 in new Qahfa station, also it showed the lowest temperature in the summer of 2018 as compared with other stations $\left(23.6{ }^{\circ} \mathrm{C}\right)$ as shown in table 1.

The drains water temperature ranged between $17.1-32.80{ }^{\circ} \mathrm{C}$. This result agreement with that reported by Mageed, (2005) and Authman and Abbas, (2007). The water temperature values showed the expected seasonal pattern with no differences between the sampling stations, coincident with that reported by Kagalou et al., (2001) and Sivri et al., (2007).

\section{The pH Values}

The results of the $\mathrm{pH}$ levels during the study period were consistent with the provisions of Law No. 48 of 1948 regarding the protection of the Nile River and its implementing regulations for the drainage of treated wastewater into aquatic environments. Where the permissible limits $(6.5-9)$. $\mathrm{pH}$ values of the different stations are slightly variable throughout the seasons and $\mathrm{pH}>7$ indicates that the alkaline water conditions prevail in the wastewater stations.

The $\mathrm{pH}$ values were found within the permissible limits and ranged from 6.8 to 7.8. The highest value was found in autumn season at Snores station, while lowest value in summer season at Atsa ( $\urcorner. \wedge)$.

\section{Solids (TS, TDS and TSS)}

The results of the total dissolved solid (TDS) during the study period were in accordance with the provisions of Law No. 48 of 1948 regarding the protection of the Nile River and its executive regulations for the disposal of treated wastewater into aquatic environments for which the maximum value was determined to be $2000 \mathrm{mg} / \mathrm{L}$.

TSS values in Atsa, Old Qahfa, New Qahfa, Tamiya, Snores and Tatoun Stations were found in the ranges of (16.0-72.7), (8.0-19.5), (30.0-134.5), (8.0-46.0), (14.0135.0) and (7.0-25.7) g/l, respectively, and the values of TDS were found (328.0-641.0), (433.3-578.0), (693.0-1014.5), (777.0-1140.3), (554.0-692.0) and (744.0-1172.0) g/l, respectively, (Figure 4)

The elevation in TDS and TSS values during summer season may be because of the high evaporation rate meanwhile their decrease during winter Seasons may be due to the temperature variation and the increase of the water level through the drainage water discharging the two drains during these seasons. These results are agreed with that reported by Authman, (2007) 
Table1: Temperature values of the influent and effluent of the six different wastewater stations at Fayoum during spring 2017 to winter 2018. All data represents means of five replicates \pm Stander Deviation (SD).

\begin{tabular}{|c|c|c|c|c|c|c|c|c|c|}
\hline \multicolumn{2}{|c|}{ Season } & Spr 2017 & $\begin{array}{l}\text { Sum } \\
2017\end{array}$ & $\begin{array}{l}\text { Aut } \\
2017\end{array}$ & Win 2018 & Spr 2018 & $\begin{array}{l}\text { Sum } \\
2018\end{array}$ & $\begin{array}{c}\text { Aut } \\
2018\end{array}$ & $\begin{array}{l}\text { Win } \\
2019\end{array}$ \\
\hline \multirow{2}{*}{ New Qahfa } & In & $23.3 \pm 0.1$ & $31.2 \pm 0.1$ & $20.2 \pm 0.1$ & $17.3 \pm 0.1$ & $23.7 \pm 0.2$ & $23.7 \pm 0.2$ & $22.2 \pm 0.2$ & $17.4 \pm 0.3$ \\
\hline & Out & $23.7 \pm 0.2$ & $31.1 \pm 0.2$ & $19.7 \pm 0.3$ & $17.1 \pm 0.2$ & $23.8 \pm 0.2$ & $23.8 \pm 0.2$ & $22.1 \pm 0.1$ & $17.3 \pm 0.1$ \\
\hline \multirow{2}{*}{ Old Qahfa } & In & $22.9 \pm 0.1$ & $30.7 \pm 0.1$ & $20.2 \pm 0.1$ & $30.0 \pm 0.1$ & $30.0 \pm 0.1$ & $30.0 \pm 0.1$ & $21 . \pm 0.2$ & $17.9 \pm 0.2$ \\
\hline & Out & $22.7 \pm 0.3$ & $30.2 \pm 0.3$ & $19.3 \pm 0.2$ & $30.0 \pm 0.3$ & $30.0 \pm 0.3$ & $30.0 \pm 0.3$ & $21.0 \pm 0.3$ & $15.4 \pm 0.1$ \\
\hline \multirow{2}{*}{ Atsa } & In & $31.5 \pm 0.01$ & $31.3 \pm 0.4$ & $21.0 \pm 0.2$ & $31.5 \pm 0.01$ & $31.5 \pm 0.1$ & $31.5 \pm 0.1$ & $21.0 \pm 0.3$ & $18.3 \pm 0.3$ \\
\hline & $\overline{\text { Out }}$ & $30.8 \pm 0.2$ & $31.7 \pm 0.2$ & $21.1 \pm 0.1$ & $30.8 \pm 0.2$ & $30.8 \pm 0.2$ & $30.8 \pm 0.2$ & $21.1 \pm 0.1$ & $18.5 \pm 0.1$ \\
\hline \multirow{2}{*}{ Taton } & In & $23.8 \pm 0.4$ & $31.5 \pm 0.1$ & $21.8 \pm 0.3$ & $30.8 \pm 0.4$ & $30.8 \pm 0.1$ & $30.8 \pm 0.1$ & $21.8 \pm 0.2$ & $18.7 \pm 0.2$ \\
\hline & Out & $23.7 \pm 0.2$ & $32.3 \pm 0.3$ & $22.2 \pm 0.1$ & $31.7 \pm 0.2$ & $31.7 \pm 0.1$ & $31.7 \pm 0.1$ & $22.2 \pm 0.2$ & $18.4 \pm 0.2$ \\
\hline \multirow{2}{*}{ Snores } & In & $23.7 \pm 0.1$ & $32.8 \pm 0.0$ & $21.5 \pm 0.4$ & $30.8 \pm 0.1$ & $30.8 \pm 0.2$ & $30.8 \pm 0.2$ & $21.5 \pm 0.2$ & $17.9 \pm 0.2$ \\
\hline & Out & $23.3 \pm 0.5$ & $32.8 \pm 0.6$ & $21.3 \pm 0.5$ & $30.1 \pm 0.5$ & $30.1 \pm 0.3$ & $30.1 \pm 0.3$ & $21.3 \pm 0.1$ & $17.1 \pm 0.2$ \\
\hline \multirow{2}{*}{ Tamyia } & In & $23.9 \pm 0.3$ & $32.1 \pm 0.1$ & $20.7 \pm 0.2$ & $31.2 \pm 0.3$ & $31.2 \pm 0.1$ & $31.2 \pm 0.1$ & $20.7 \pm 0.3$ & $17.6 \pm 0.3$ \\
\hline & Out & $23.7 \pm 0.2$ & $32.3 \pm 0.2$ & $20.8 \pm 0.0$ & $31.4 \pm 0.2$ & $31.4 \pm 0.1$ & $31.4 \pm 0.1$ & $20.8 \pm 0.1$ & $17.6 \pm 0.1$ \\
\hline
\end{tabular}




(s)

Figure 4: TSS and TDS of the influent and effluent of the 6 different wastewater stations at El-Fayoum. All data represents means of five replicates \pm Stander Deviation (SD), TSS: Total suspended solids, TDS: total dissolved solutes, IN: Influent (untreated raw wastewater) and out: Effluent (treated wastewater). 


\section{Oxygen (DO, COD and BOD)}

Some results of the ( COD, BOD, DO ) analysis during the study period were higher than the value approved by Law No. 48 of 1948, as the maximum value for the COD 80mg/l , BOD $60 \mathrm{mg} / \mathrm{l}$ and DO 4mg/l .

The concentration values of COD was found in the ranges of $329.3-261.5 \mathrm{mg} / \mathrm{L}$ at Old Qahfa station (2017) in autumn season and at Atsa station in the winter season (2019), respectively. While DO was found between 0.1-7.6 mg/L in Atsa station in the spring season of 2018 and at the New Qahfa station in the winter season of 2018, respectively (Figure 4).

The highest value of BOD $(100 \mathrm{mg} / \mathrm{L})$ was found in Atsa station in autumn, winter and summer seasons of 2018 which means significant entry of organic pollution load.

On the other hand, the highest value of DO $(7.6 \mathrm{mg} / \mathrm{L})$ was recorded during winter of 2018 (Figure 4). The main reason for this could be attributed to the decrease in temperature, the prevailing wind action allowing the solubility of atmospheric oxygen gas to increase. The DO values showed relative decrease during spring and summer which may mainly attributed to increasing of water temperature that leads to decrease in the solubility of the oxygen gas. Also, the oxidation of organic matter by microorganisms that consume part of dissolved oxygen. These results was agreement with Sabae and Mohamed, (2015); Al-Afify et al., (2018), who reported that, the general annual average concentrations is $7.57 \mathrm{mg} / \mathrm{l}$.

Generally, higher values of DO, BOD and COD are indicators for higher microbial activity. This was reflected in somewhat elevated $\mathrm{NH}_{4}^{+}, \mathrm{NO}_{2}^{-}$and $\mathrm{NO}^{-}$ values.

\section{Nutrient salts}

Nutrient salts $\left(\mathrm{NO}_{3}^{-}, \mathrm{NO}_{2}^{-}, \mathrm{NH}_{3}\right.$ and $\left.\mathrm{PO}_{4}{ }^{3-}\right)$ play an important role in the productivity of aquatic ecosystems promoting the food chain for phytoplankton and zooplankton as well as fish (Abdo, 2004). Nitrite is an important intermediate of the bacterial aerobic nitrification process formed by the autotrophic nitrosamine bacteria combining oxygen and ammonia (Liu et al., 2009).

Nitrate $\left(\mathrm{NO}_{3}{ }^{-}\right)$can get directly into the water as a result of fertilizer runoff. The concentration levels of $\mathrm{NO}_{2}{ }^{-}, \mathrm{NO}_{3}{ }^{-}$and $\mathrm{NH}_{3}{ }^{-}$were found in the ranges of (0.0-8.0), (4.4104.5) and (1.1-43.0) $\mathrm{mg} / \mathrm{L}$ respectively (Table 2, 3 and 4). These nutrients increase with runoff from agricultural land, especially intensively cultivated land with large inputs of synthetic fertilizers) and urban wastewater, resulting in eutrophication (Bhatnagar and Devi, 2013). 
Phosphorus enters the aquatic system from anthropogenic sources, as fertilizer runoff, may theoretically be converted into either an inorganic or an organic fraction. As phosphorus builds up within the lake, it can cycle through the water column and facilitate algal blooms forever (Edwards and Withers, 2008).

The concentrations levels of $\mathrm{PO}_{4}{ }^{3-}$ were found to be in the ranges of 1.0-42.1 $\mathrm{mg} / \mathrm{L}$ as shown in Tables (5). The concentration of phosphates can be explained on the basis of the high amount of agricultural runoff and the inflow of domestic sewage from the adjacent cultivated land and the neighboring villages to the drains (Abdo, 2004).
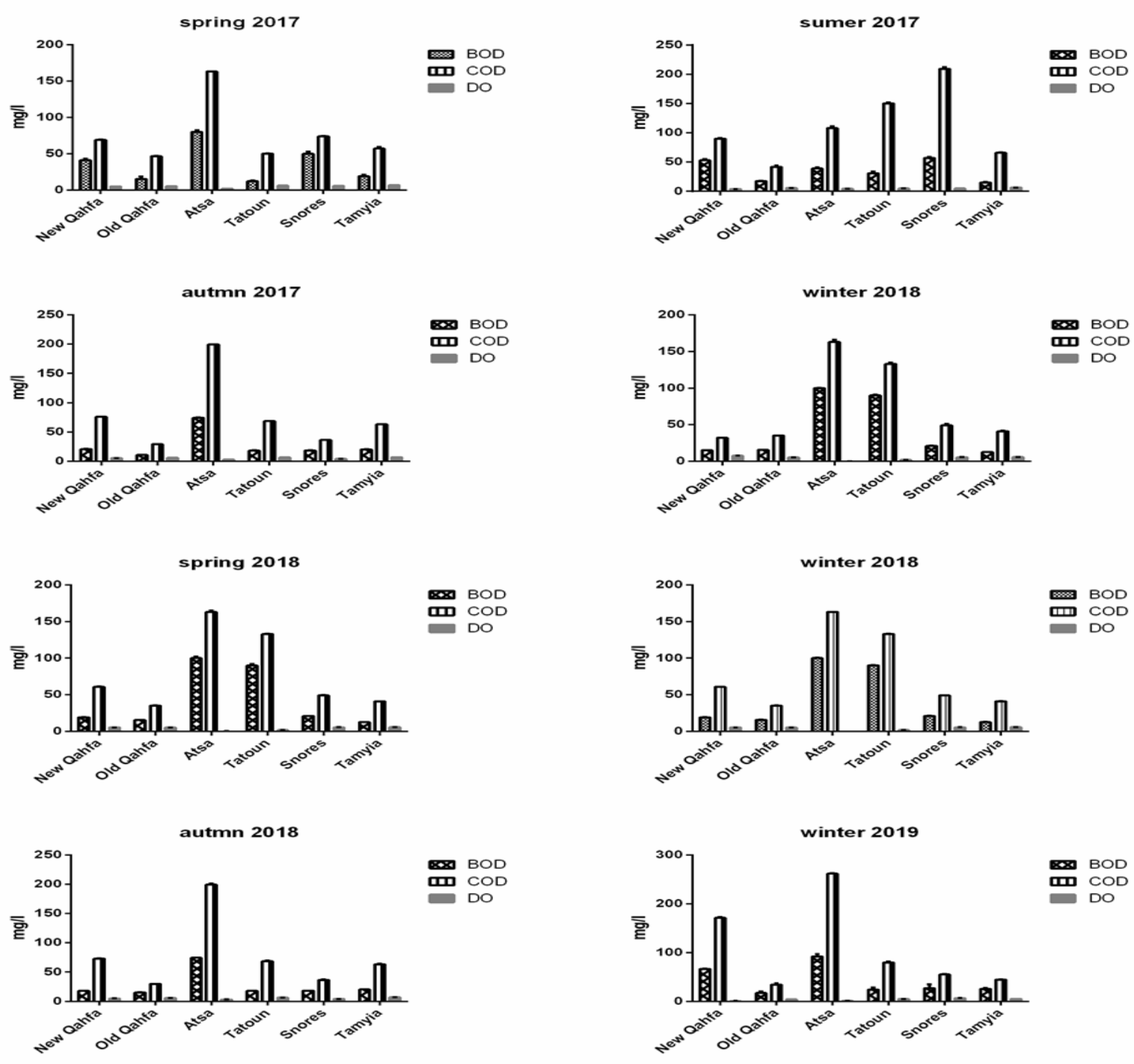

Figure 4: Biological oxygen demand (BOD), Chemical oxygen demand (COD) and Dissolved oxygen (DO) of the effluent for the different 6 stations in Fayoum Governorate during spring 2017 to winter 2018. 
Table 2: Nitrate contents $\left(\mathrm{NO}_{3}{ }^{-}, \mathrm{mg} / \mathrm{L}\right)$ in 6 wastewater stations of the influent and effluent during spring 2017 to winter 2019 . All data represents means of five replicates \pm SD.

\begin{tabular}{|c|c|c|c|c|c|c|c|c|c|c|c|c|c|c|c|c|}
\hline \multirow{2}{*}{$\begin{array}{c}\text { Season } \\
\text { nitrate } \\
\text { Statio } \\
\text { n }\end{array}$} & \multicolumn{2}{|c|}{ Spr 2017} & \multicolumn{2}{|c|}{ Sum 2017} & \multicolumn{2}{|c|}{ Aut2017 } & \multicolumn{2}{|c|}{ Win 2018} & \multicolumn{2}{|c|}{ Spr 2018} & \multicolumn{2}{|c|}{ Sum 2018} & \multicolumn{2}{|c|}{ Aut 2018} & \multicolumn{2}{|c|}{ Win 2019} \\
\hline & Inf & Eff & Inf & Eff & Inf & Eff & Inf & Eff & Inf & Eff & Inf & Eff & Inf & Eff & Inf & Eff \\
\hline $\begin{array}{l}\text { New } \\
\text { Qahfa }\end{array}$ & N.D & $\begin{array}{l}0.05 \pm 0 . \\
1\end{array}$ & \multicolumn{2}{|c|}{ N.D } & \multicolumn{2}{|c|}{ N.D } & N.D & $\begin{array}{l}0.2 \pm 0 . \\
1\end{array}$ & $\begin{array}{l}0.4 \pm . \\
02\end{array}$ & $\begin{array}{l}0.1 \pm 0 \\
.0\end{array}$ & $\begin{array}{l}\text { N. } \\
\text { D }\end{array}$ & & $\begin{array}{l}\text { N. } \\
\text { D }\end{array}$ & $\begin{array}{l}0.2 \pm 0 . \\
1\end{array}$ & $\begin{array}{l}\text { N. } \\
\text { D }\end{array}$ & N.D \\
\hline $\begin{array}{c}\text { Old } \\
\text { Qahfa } \\
\end{array}$ & N.D & $0.4 \pm 0.2$ & $\begin{array}{l}0.3 \pm 0 \\
.1 \\
\end{array}$ & $\begin{array}{l}1.5 \pm 0 \\
.1 \\
\end{array}$ & N.D & $\begin{array}{l}2.2 \pm 0 \\
.2 \\
\end{array}$ & $\begin{array}{l}0.1 \pm 0 \\
.0 \\
\end{array}$ & $\begin{array}{l}3.3 \pm 0 . \\
1 \\
\end{array}$ & N.D & $\begin{array}{l}0.8 \pm 0 \\
.0 \\
\end{array}$ & $\begin{array}{l}\text { N. } \\
\text { D }\end{array}$ & $0.3 \pm 0.1$ & $\begin{array}{l}\text { N. } \\
\text { D }\end{array}$ & $\begin{array}{l}0.2 \pm 0 . \\
1 \\
\end{array}$ & $\begin{array}{l}\text { N. } \\
\text { D }\end{array}$ & $\begin{array}{l}0.8 \pm 0 . \\
01 \\
\end{array}$ \\
\hline Atsa & N.D & $0.1 \pm 0.0$ & \multicolumn{2}{|c|}{ N.D } & \multicolumn{2}{|c|}{ N.D } & \multicolumn{2}{|c|}{ N.D } & N.D & $\begin{array}{l}0.1 \pm . \\
01\end{array}$ & \multicolumn{2}{|c|}{ N.D } & $\begin{array}{l}\text { N. } \\
\text { D }\end{array}$ & $\begin{array}{l}0.1 \pm 0 . \\
1\end{array}$ & $\begin{array}{l}\text { N. } \\
\text { D }\end{array}$ & N.D \\
\hline $\begin{array}{c}\text { Tatou } \\
\mathbf{n}\end{array}$ & N.D & $\begin{array}{l}1.67 \pm 0 . \\
1\end{array}$ & \multicolumn{2}{|c|}{ N.D } & N.D & $\begin{array}{l}0.3 \pm 0 \\
.0\end{array}$ & \multicolumn{2}{|c|}{ N.D } & \multicolumn{2}{|c|}{ N.D } & \multicolumn{2}{|c|}{ N.D } & $\begin{array}{l}\text { N. } \\
\text { D }\end{array}$ & $\begin{array}{l}0.2 \pm 0 \\
1\end{array}$ & $\begin{array}{l}\text { N. } \\
\text { D }\end{array}$ & $\begin{array}{l}0.3 \pm 0 \text {. } \\
01\end{array}$ \\
\hline $\begin{array}{c}\text { Snore } \\
\mathrm{S}\end{array}$ & $\begin{array}{l}0.16 \pm 0 . \\
1\end{array}$ & $5.5 \pm 0.1$ & N.D & $\begin{array}{l}1.4 \pm 0 \\
.1\end{array}$ & $\begin{array}{l}2.9 \pm 0 \\
.1\end{array}$ & $\begin{array}{l}1.7 \pm 0 \\
.0\end{array}$ & N.D & $\begin{array}{l}1.4 \pm 0 \text {. } \\
1\end{array}$ & N.D & $\begin{array}{l}0.8 \pm 0 \\
.1\end{array}$ & $\begin{array}{l}\text { N. } \\
\text { D }\end{array}$ & $\begin{array}{l}0.53 \pm 0 . \\
02\end{array}$ & $\begin{array}{l}\text { N. } \\
\text { D }\end{array}$ & $\begin{array}{l}0.2 \pm 0 . \\
1\end{array}$ & $\begin{array}{l}\text { N. } \\
\text { D }\end{array}$ & $\begin{array}{l}0.2 \pm 0 . \\
02\end{array}$ \\
\hline $\begin{array}{c}\text { Tamy } \\
\text { ia }\end{array}$ & N.D & $\begin{array}{l}0.05 \pm 0 . \\
1\end{array}$ & N.D & $\begin{array}{l}8.4 \pm 0 \\
.3\end{array}$ & N.D & $\begin{array}{l}0.1 \pm 0 \\
.1\end{array}$ & $\begin{array}{l}0.4 \pm 0 \\
.1\end{array}$ & $\begin{array}{l}5.2 \pm 0 . \\
2\end{array}$ & N.D & N.D & $\begin{array}{l}\text { N. } \\
\text { D }\end{array}$ & $\begin{array}{l}0.04 \pm 0 \text {. } \\
01\end{array}$ & $\begin{array}{l}\text { N. } \\
\text { D }\end{array}$ & $\begin{array}{l}1.5 \pm 0 \\
1\end{array}$ & $\begin{array}{l}\text { N. } \\
\text { D }\end{array}$ & $\begin{array}{l}0.2 \pm 0 \\
01\end{array}$ \\
\hline
\end{tabular}

Inf: Influent (untreated raw wastewater) and Eff: Effluent (treated wastewater) 
Table 3: Nitrite contents $\left(\mathrm{NO}_{2}{ }^{-}, \mathrm{mg} / \mathrm{L}\right)$ in 6 wastewater stations of the influent and effluent during spring 2017 to winter 2019 . All data represents means of five replicates $\pm \mathrm{SD}$.

\begin{tabular}{|c|c|c|c|c|c|c|c|c|c|c|c|c|c|c|c|c|}
\hline \multirow{2}{*}{$\begin{array}{l}\text { Station } \\
\text { treatment }\end{array}$} & \multicolumn{2}{|c|}{ Spr 2017} & \multicolumn{2}{|c|}{ Sum 2017} & \multicolumn{2}{|c|}{ Aut2017 } & \multicolumn{2}{|c|}{ Win 2018} & \multicolumn{2}{|c|}{ Spr 2018} & \multicolumn{2}{|c|}{ Sum 2018} & \multicolumn{2}{|c|}{ Aut 2018} & \multicolumn{2}{|c|}{ Win 2019} \\
\hline & Inf & & & & Inf & Eff & Inf & Eff & Inf & Eff & Inf & Eff & Inf & Eff & Inf & Eff \\
\hline $\begin{array}{l}\text { New } \\
\text { Qahfa }\end{array}$ & $\begin{array}{r}17.1 \\
\pm 0.2\end{array}$ & $\begin{array}{c}6.7 \\
\pm 0.1\end{array}$ & $\begin{array}{r}15.1 \\
\pm 0.1\end{array}$ & $\begin{array}{c}9.5 \\
\pm 0.2\end{array}$ & $\begin{array}{c}19.3 \\
\pm 0.03\end{array}$ & $\begin{array}{c}9.2 \\
\pm 0.02\end{array}$ & $\begin{array}{c}21.9 \\
\pm 0.02\end{array}$ & $\begin{array}{c}8.9 \\
\pm 0.01\end{array}$ & $\begin{array}{c}19.9 \\
\pm 0.14\end{array}$ & $\begin{array}{c}7.7 \\
\mathbf{\pm 0 . 0 1}\end{array}$ & $\begin{array}{c}13.7 \\
\mathbf{\pm 0 . 4 1}\end{array}$ & $\begin{array}{l}10.2 \\
\pm 0.1\end{array}$ & $\begin{array}{c}21.9 \\
\pm 0.21\end{array}$ & $\begin{array}{c}8.9 \\
\pm 0.31\end{array}$ & $\begin{array}{c}15.2 \\
\pm 0.10\end{array}$ & $\begin{array}{r}15.6 \\
\pm 0.12\end{array}$ \\
\hline $\begin{array}{c}\text { Old } \\
\text { Qahfa }\end{array}$ & $\begin{array}{l}19.1 \\
\pm 0.1\end{array}$ & $\begin{array}{c}5.5 \\
\pm 0.2\end{array}$ & $\begin{array}{l}18.1 \\
\pm 0.1\end{array}$ & $\begin{array}{r}19.3 \\
\pm 0.1\end{array}$ & $\begin{array}{c}18.9 \\
\pm 0.01\end{array}$ & $\begin{array}{l}47.5 \\
\pm 0.2\end{array}$ & $\begin{array}{r}25.3 \\
\pm 0.03\end{array}$ & $\begin{array}{c}16.1 \\
\pm 0.01\end{array}$ & $\begin{array}{r}21.4 \\
\pm 0.13\end{array}$ & $\begin{array}{c}24.5 \\
\pm 0.14\end{array}$ & $\begin{array}{c}15.4 \\
\pm 0.01\end{array}$ & $\begin{array}{c}4.4 \\
\pm 0.1\end{array}$ & $\begin{array}{c}23.3 \\
\pm 0.06\end{array}$ & $\begin{array}{c}6.1 \\
\pm 0.01\end{array}$ & $\begin{array}{c}16.6 \\
\pm 0.10\end{array}$ & $\begin{array}{c}6.7 \\
\pm 0.1\end{array}$ \\
\hline Atsa & $\begin{array}{l}23.9 \\
\pm 0.3\end{array}$ & $\begin{array}{r}14.1 \\
\pm 0.2\end{array}$ & $\begin{array}{r}23.3 \\
\pm 0.2\end{array}$ & $\begin{array}{r}10.5 \\
\pm 0.2\end{array}$ & $\begin{array}{c}19.3 \\
\pm 0.01\end{array}$ & $\begin{array}{r}14.6 \\
\pm 0.1\end{array}$ & $\begin{array}{c}30.7 \\
\mathbf{+ 0 . 0 4}\end{array}$ & $\begin{array}{r}12.6 \\
\pm 0.1\end{array}$ & $\begin{array}{c}23.9 \\
\pm 0.14\end{array}$ & $\begin{array}{c}14.1 \\
\pm 0.12\end{array}$ & $\begin{array}{c}17.5 \\
\pm 0.12\end{array}$ & $\begin{array}{r}14.7 \\
\pm 0.1\end{array}$ & $\begin{array}{c}21 \\
\pm 0.12\end{array}$ & $\begin{array}{l}12.2 \\
\pm 0.1\end{array}$ & $\begin{array}{r}17.4 \\
\pm 015\end{array}$ & $\begin{array}{c}8.5 \\
\pm 0.1\end{array}$ \\
\hline Tatoun & $\begin{array}{c}157.8 \\
\pm 0.5\end{array}$ & $\begin{array}{r}11.3 \\
\pm 0.2\end{array}$ & $\begin{array}{r}19.7 \\
\pm 0.1\end{array}$ & $\begin{array}{r}12.6 \\
\pm 0.2\end{array}$ & $\begin{array}{c}25.6 \\
\pm 0.02\end{array}$ & $\begin{array}{c}13.8 \\
\pm 0.01\end{array}$ & $\begin{array}{c}26.4 \\
\pm 0.03\end{array}$ & $\begin{array}{c}7.6 \\
\pm 0.01\end{array}$ & $\begin{array}{c}29.5 \\
\pm 0.21\end{array}$ & $\begin{array}{c}15 \\
\pm 0.11\end{array}$ & $\begin{array}{r}29.4 \\
\pm 0.11\end{array}$ & $\begin{array}{r}13.1 \\
\pm 0.1\end{array}$ & $\begin{array}{c}24.9 \\
\pm 0.11\end{array}$ & $\begin{array}{c}8.2 \\
\pm 0.1\end{array}$ & $\begin{array}{c}16.6 \\
\pm 0.11\end{array}$ & $\begin{array}{r}12.8 \\
\pm 0.1\end{array}$ \\
\hline Snores & $\begin{array}{l}25.9 \\
\pm 0.2\end{array}$ & $\begin{array}{r}66.6 \\
\pm 0.3\end{array}$ & $\begin{array}{r}22.2 \\
\pm 0.1\end{array}$ & $\begin{array}{r}57.3 \\
\pm 0.1\end{array}$ & $\begin{array}{c}66 \\
\pm 0.01\end{array}$ & $\begin{array}{r}52.5 \\
\pm 0.03\end{array}$ & $\begin{array}{l}35.5 \\
\pm 0.1\end{array}$ & $\begin{array}{c}11.6 \\
\pm 0.04\end{array}$ & $\begin{array}{c}34.8 \\
\pm 0.10\end{array}$ & $\begin{array}{c}9.5 \\
\pm 0.12\end{array}$ & $\begin{array}{r}22.3 \\
\pm 0.17\end{array}$ & $\begin{array}{c}7.9 \\
\pm 0.1\end{array}$ & $\begin{array}{c}20.4 \\
\pm 0.18\end{array}$ & $\begin{array}{c}5.9 \\
\pm 0.01\end{array}$ & $\begin{array}{c}29 \\
\pm 0.11\end{array}$ & $\begin{array}{r}17.9 \\
\pm 0.1\end{array}$ \\
\hline Tamyia & $\begin{array}{r}19.6 \\
\pm 0.2\end{array}$ & $\begin{array}{r}48.6 \\
\pm 0.1\end{array}$ & $\begin{array}{r}19.1 \\
\pm 0.2\end{array}$ & $\begin{array}{c}8.1 \\
\pm 0.3\end{array}$ & $\begin{array}{l}37.2 \\
\pm 0.1\end{array}$ & $\begin{array}{c}7.8 \\
\pm 0.1\end{array}$ & $\begin{array}{c}34.8 \\
\pm 0.13\end{array}$ & $\begin{array}{r}104.5 \\
\pm 0.02\end{array}$ & $\begin{array}{r}39.3 \\
\pm 0.01\end{array}$ & $\begin{array}{c}99.6 \\
\pm 0.11\end{array}$ & $\begin{array}{r}16.25 \\
\pm 0.51\end{array}$ & $\begin{array}{r}19.6 \\
\pm 0.1\end{array}$ & $\begin{array}{c}30.9 \\
\pm 0.02\end{array}$ & $\begin{array}{c}12.7 \\
\pm 0.11\end{array}$ & $\begin{array}{c}22.7 \\
\pm 0.41\end{array}$ & $\begin{array}{l}6.26 \\
\pm 0.1\end{array}$ \\
\hline
\end{tabular}

Inf: Influent (untreated raw wastewater) and Eff: Effluent (treated wastewater) 
Table 4: Amonia contents $\left(\mathrm{NH}_{3}{ }^{-}, \mathrm{mg} / \mathrm{L}\right)$ in 6 wastewater stations of the influent and effluent during spring 2017 to winter 2019 . All data represents means of five replicates $\pm \mathrm{SD}$.

\begin{tabular}{|c|c|c|c|c|c|c|c|c|c|c|c|c|c|c|c|c|}
\hline \multirow{2}{*}{$\begin{array}{l}\text { Station } \\
\text { treatment }\end{array}$} & \multicolumn{2}{|c|}{ Spr 2017} & \multicolumn{2}{|c|}{ Sum 2017} & \multicolumn{2}{|c|}{ Aut2017 } & \multicolumn{2}{|c|}{ Win 2018} & \multicolumn{2}{|c|}{ Spr 2018} & \multicolumn{2}{|c|}{ Sum 2018} & \multicolumn{2}{|c|}{ Aut 2018} & \multicolumn{2}{|c|}{ Win 2019} \\
\hline & Inf & Eff & Inf & Eff & Inf & Eff & Inf & Eff & Inf & Eff & Inf & Eff & Inf & Eff & Inf & Eff \\
\hline New Qahfa & $\begin{array}{r}29.8 \\
\pm 0.2\end{array}$ & $\begin{array}{r}19.32 \\
\pm 0.01\end{array}$ & $\begin{array}{r}18.5 \\
\pm 0.02\end{array}$ & $\begin{array}{r}17.9 \\
\pm 0.03\end{array}$ & $\begin{array}{r}28.3 \\
\pm 0.02\end{array}$ & $\begin{array}{c}19 \\
\pm 0.01\end{array}$ & $\begin{array}{r}35.1 \\
\pm 0.1\end{array}$ & $\begin{array}{c}19 \\
\pm 0.1\end{array}$ & $\begin{array}{r}29.8 \\
\pm 0.1\end{array}$ & $\begin{array}{r}22.8 \\
\pm 0.1\end{array}$ & $\begin{array}{c}23 \\
\pm 0.1\end{array}$ & $\begin{array}{c}24 \\
\pm 0.11\end{array}$ & $\begin{array}{c}35 \\
\pm 0.11\end{array}$ & $\begin{array}{c}19 \\
\pm 0.1\end{array}$ & $\begin{array}{r}27.9 \\
\pm 0.16\end{array}$ & $\begin{array}{r}25.3 \\
\pm 0.11\end{array}$ \\
\hline Old Qahfa & $\begin{array}{r}29.12 \\
\pm 0.2\end{array}$ & $\begin{array}{r}3.19 \\
\pm 0.02\end{array}$ & $\begin{array}{l}31.4 \\
\pm 0.1\end{array}$ & $\begin{array}{c}4.2 \\
\pm 0.01\end{array}$ & $\begin{array}{r}32.1 \\
\pm 0.02\end{array}$ & $\begin{array}{c}2.5 \\
\pm 0.05\end{array}$ & $\begin{array}{c}36.1 \\
\pm 0.12\end{array}$ & $\begin{array}{c}3.5 \\
\pm 0.01\end{array}$ & $\begin{array}{r}57.5 \\
\pm 0.15\end{array}$ & $\begin{array}{c}4.2 \\
\pm 0.01\end{array}$ & $\begin{array}{r}24.5 \\
\pm 0.11\end{array}$ & $\begin{array}{r}4.8 \\
\pm 0.1\end{array}$ & $\begin{array}{l}36 \\
\pm 0.12\end{array}$ & $\begin{array}{r}15.5 \\
\pm 0.11\end{array}$ & $\begin{array}{r}26.2 \\
\pm 0.15\end{array}$ & $\begin{array}{c}8.5 \\
\pm 0.12\end{array}$ \\
\hline Atsa & $\begin{array}{r}49.3 \\
\pm 0.2\end{array}$ & $\begin{array}{r}27.3 \\
\pm 0.1\end{array}$ & $\begin{array}{r}50.7 \\
\pm 0.2\end{array}$ & $\begin{array}{r}31.3 \\
\pm 0.02\end{array}$ & $\begin{array}{r}36.3 \\
\pm 0.1\end{array}$ & $\begin{array}{r}31.4 \\
\pm 0.1\end{array}$ & $\begin{array}{r}74.5 \\
\pm 0.14\end{array}$ & $\begin{array}{r}41.3 \\
\pm 0.12\end{array}$ & $\begin{array}{r}49.3 \\
\pm 0.11\end{array}$ & $\begin{array}{r}27.3 \\
\pm 0.12\end{array}$ & $\begin{array}{r}34.1 \\
\pm 0.1\end{array}$ & $\begin{array}{r}33.2 \\
\pm 0.11\end{array}$ & $\begin{array}{c}44 \\
\pm 0.12\end{array}$ & $\begin{array}{r}28.4 \\
\pm 0.1\end{array}$ & $\begin{array}{r}43.3 \\
\pm 0.15\end{array}$ & $\begin{array}{r}35.8 \\
\pm 0.13\end{array}$ \\
\hline Tatoun & $\begin{array}{r}69.49 \\
\pm 0.3\end{array}$ & $\begin{array}{l}11.4 \\
\pm 0.1\end{array}$ & $\begin{array}{r}45.8 \\
\pm 0.02\end{array}$ & $\begin{array}{r}32.5 \\
\pm 0.01\end{array}$ & $\begin{array}{r}48.3 \\
\pm 0.01\end{array}$ & $\begin{array}{r}32.6 \\
\pm 0.06\end{array}$ & $\begin{array}{r}49.3 \\
\pm 0.15\end{array}$ & $\begin{array}{r}42.6 \\
\pm 0.16\end{array}$ & $\begin{array}{r}49.3 \\
\pm 0.11\end{array}$ & $\begin{array}{r}33.3 \\
\pm 0.15\end{array}$ & $\begin{array}{l}39.7 \\
\pm 0.1\end{array}$ & $\begin{array}{r}41.2 \\
\pm 0.1\end{array}$ & $\begin{array}{r}53.2 \\
\pm 0.12\end{array}$ & $\begin{array}{c}23 \\
\pm 0.12\end{array}$ & $\begin{array}{c}42 \\
\pm 0.15\end{array}$ & $\begin{array}{c}37 \\
\pm \mathbf{0 . 1 2}\end{array}$ \\
\hline Snores & $\begin{array}{r}57.17 \\
\pm 0.2\end{array}$ & $\begin{array}{r}6.16 \\
\pm 0.01\end{array}$ & $\begin{array}{r}35.3 \\
\pm 0.03\end{array}$ & $\begin{array}{r}5.5 \\
\pm 0.1\end{array}$ & $\begin{array}{l}35.1 \\
\pm 0.1\end{array}$ & $\begin{array}{c}7.3 \\
\pm 0.08\end{array}$ & $\begin{array}{r}79.4 \\
\pm 0.1\end{array}$ & $\begin{array}{r}35.8 \\
\pm 0.10\end{array}$ & $\begin{array}{r}49.3 \\
\pm 0.1\end{array}$ & $\begin{array}{r}16.5 \\
\pm 0.12\end{array}$ & $\begin{array}{c}35 \\
\pm 0.1\end{array}$ & $\begin{array}{c}7.6 \\
\pm 0.15\end{array}$ & $\begin{array}{l}36 \\
\pm 0.1\end{array}$ & $\begin{array}{c}23 \\
\pm 0.1\end{array}$ & $\begin{array}{c}47 \\
\pm 0.12\end{array}$ & $\begin{array}{r}21.8 \\
\pm 0.12\end{array}$ \\
\hline Tamyia & $\begin{array}{r}38.52 \\
\pm 0.1\end{array}$ & $\begin{array}{r}34.6 \\
\pm 0.2\end{array}$ & $\begin{array}{r}27.4 \\
\pm 0.2\end{array}$ & $\begin{array}{c}8.9 \\
\pm 0.3\end{array}$ & $\begin{array}{r}65.5 \\
\pm 0.31\end{array}$ & $\begin{array}{r}31.1 \\
\pm 0.21\end{array}$ & $\begin{array}{c}47 \\
\pm 0.15\end{array}$ & $\begin{array}{c}9.2 \\
\pm 0.16\end{array}$ & $\begin{array}{r}64.7 \\
\pm 0.14\end{array}$ & $\begin{array}{c}1.7 \\
\pm 0.01\end{array}$ & $\begin{array}{r}40.6 \\
\pm 0.12\end{array}$ & $\begin{array}{l}8.9 \\
\pm 0.1\end{array}$ & $\begin{array}{c}54 \\
\pm 0.1\end{array}$ & $\begin{array}{c}2 \\
\pm 0.11\end{array}$ & $\begin{array}{c}50.1 \\
\pm 0.12\end{array}$ & $\begin{array}{c}1.1 \\
\pm 0.12\end{array}$ \\
\hline
\end{tabular}


Inf: Influent (untreated raw wastewater) and Eff: Effluent (treated wastewater)

Table 5: Phosphorus contents $\left(\mathrm{PO}_{4}^{-}, \mathrm{mg} / \mathrm{L}\right)$ in 6 wastewater stations of the influent and effluent during spring 2017 to winter 2019 . All data represents means of five replicates $\pm \mathrm{SD}$.

\begin{tabular}{|c|c|c|c|c|c|c|c|c|c|c|c|c|c|c|c|c|}
\hline \multirow{2}{*}{$\begin{array}{r}\text { Station } \\
\text { treatmen } \\
\mathbf{t}\end{array}$} & \multicolumn{2}{|c|}{ Spr 2017} & \multicolumn{2}{|c|}{ Sum 2017} & \multicolumn{2}{|c|}{ Aut2017 } & \multicolumn{2}{|c|}{ Win 2018} & \multicolumn{2}{|c|}{ Spr 2018} & \multicolumn{2}{|c|}{ Sum 2018} & \multicolumn{2}{|c|}{ Aut 2018} & \multicolumn{2}{|c|}{ Win 2019} \\
\hline & Inf & Eff & Inf & Eff & Inf & Eff & Inf & Eff & Inf & Eff & Inf & Eff & Inf & Eff & Inf & Eff \\
\hline $\begin{array}{c}\text { New } \\
\text { Qahfa }\end{array}$ & $\begin{array}{r}11.6 \\
\pm 0.01\end{array}$ & $\begin{array}{c}4.4 \\
\pm 0.0 \\
1\end{array}$ & $\begin{array}{r}8.3 \\
\pm 0.1\end{array}$ & $\begin{array}{c}2.6 \\
\pm 0 . \\
1\end{array}$ & $\begin{array}{c}44 \\
\pm 0.01\end{array}$ & $\begin{array}{r}0.9 \\
\pm 0.1\end{array}$ & $\begin{array}{c}6.7 \\
\pm 0.11\end{array}$ & $\begin{array}{c}5.9 \\
\pm 0.41\end{array}$ & $\begin{array}{c}5.2 \\
\pm 0.1 \\
1\end{array}$ & $\begin{array}{c}1 \\
\pm 0.1\end{array}$ & $\begin{array}{r}25.3 \\
\pm 0.1\end{array}$ & $\begin{array}{c}24.31 \\
\pm 0.1 \\
1\end{array}$ & $\begin{array}{l}16.7 \\
\pm 0.1\end{array}$ & $\begin{array}{r}5.9 \\
\pm 0.1\end{array}$ & $\begin{array}{r}4.4 \\
\pm 0.1\end{array}$ & $\begin{array}{c}3.1 \\
\pm 0 . \\
1\end{array}$ \\
\hline $\begin{array}{c}\text { Old } \\
\text { Qahfa }\end{array}$ & $\begin{array}{r}10.8 \\
\pm 0.2\end{array}$ & $\begin{array}{c}0.88 \\
\pm 0.0 \\
1 \\
\end{array}$ & $\begin{array}{r}7.1 \\
\pm 0.01\end{array}$ & $\begin{array}{c}9.9 \\
\pm 0 . \\
2 \\
\end{array}$ & $\begin{array}{c}4.7 \\
\pm 0.02\end{array}$ & $\begin{array}{c}2.7 \\
\pm 0.02\end{array}$ & $\begin{array}{c}7 \\
\pm 0.12\end{array}$ & $\begin{array}{c}3.5 \\
\pm 0.13\end{array}$ & $\begin{array}{c}0.6 .2 \\
\pm 0.1 \\
3 \\
\end{array}$ & $\begin{array}{r}3.6 \\
\pm 0.1\end{array}$ & $\begin{array}{l}0.25 \\
\pm 0.1\end{array}$ & $\begin{array}{r}9.5 \\
\pm 0.1\end{array}$ & $\begin{array}{c}14.8 \\
\pm 0.1 \\
2 \\
\end{array}$ & $\begin{array}{r}5.5 \\
\pm 0.1\end{array}$ & $\begin{array}{r}4.1 \\
\pm 0.1\end{array}$ & $\begin{array}{r}2 \\
\pm 0 . \\
1\end{array}$ \\
\hline Atsa & $\begin{array}{c}9 \\
\pm 0.1\end{array}$ & $\begin{array}{r}6.6 \\
\pm 0.1\end{array}$ & $\begin{array}{r}13.1 \\
\pm 0.1\end{array}$ & $\begin{array}{c}3.9 \\
\pm 0 . \\
1 \\
\end{array}$ & $\begin{array}{r}13.7 \\
\pm 0.01\end{array}$ & $\begin{array}{c}6.2 \\
\pm 0.01\end{array}$ & $\begin{array}{r}13.8 \\
\pm 0.15\end{array}$ & $\begin{array}{c}2.6 \\
\pm 0.12\end{array}$ & $\begin{array}{c}5 \\
\pm 0.1 \\
5 \\
\end{array}$ & $\begin{array}{c}4.4 \\
\pm 0.1 \\
3 \\
\end{array}$ & $\begin{array}{c}44.8 \\
\pm 0.1 \\
1 \\
\end{array}$ & $\begin{array}{c}4.3 \\
\pm 0.1 \\
2 \\
\end{array}$ & $\begin{array}{r}15.7 \\
\pm 0.1\end{array}$ & $\begin{array}{c}7.8 \\
\pm 0.0 \\
1 \\
\end{array}$ & $\begin{array}{c}6.1 \\
\pm 0.1\end{array}$ & $\begin{array}{c}2.7 \\
\pm 0 . \\
1\end{array}$ \\
\hline Tatoun & $\begin{array}{r}19.1 \\
\pm 0.2\end{array}$ & $\begin{array}{r}5.14 \\
\pm 0.1\end{array}$ & $\begin{array}{c}18 \\
\pm 0.2\end{array}$ & $\begin{array}{c}6.3 \\
\pm 0 . \\
01 \\
\end{array}$ & $\begin{array}{c}9 \\
\pm 0.03\end{array}$ & $\begin{array}{c}3.1 \\
\pm \mathbf{0 . 0 3}\end{array}$ & $\begin{array}{c}7.5 \\
\pm 0.19\end{array}$ & $\begin{array}{c}1.3 \\
\pm 0.14\end{array}$ & $\begin{array}{c}4.5 \\
\pm 0.1 \\
5 \\
\end{array}$ & $\begin{array}{c}4.2 \\
\pm 0.1 \\
1 \\
\end{array}$ & $\begin{array}{r}47.6 \\
\pm 0.1\end{array}$ & $\begin{array}{c}42.1 \\
\pm 0.1 \\
3 \\
\end{array}$ & $\begin{array}{c}14 \\
\pm 0.1 \\
1 \\
\end{array}$ & $\begin{array}{c}4.6 \\
\pm 0.1 \\
3 \\
\end{array}$ & $\begin{array}{c}6.6 \\
\pm 0.1 \\
2 \\
\end{array}$ & $\begin{array}{r}3.4 \\
\pm 0 . \\
1 \\
\end{array}$ \\
\hline Snores & $\begin{array}{c}13 \\
\pm 0.2\end{array}$ & $\begin{array}{r}8.6 \\
\pm 0.1\end{array}$ & $\begin{array}{r}7.3 \\
\pm 0.1\end{array}$ & $\begin{array}{c}4.6 \\
\pm 0 . \\
1 \\
\end{array}$ & $\begin{array}{r}7.6 \\
\pm 0.01\end{array}$ & $\begin{array}{c}5 \\
\pm 0.0\end{array}$ & $\begin{array}{c}18 \\
\pm 0.13\end{array}$ & $\begin{array}{c}4.1 \\
\pm 0.15\end{array}$ & $\begin{array}{c}4.8 \\
\pm 0.1 \\
9 \\
\end{array}$ & $\begin{array}{c}2.3 \\
\pm 0.1 \\
3 \\
\end{array}$ & $\begin{array}{c}62.6 \\
\pm 0.1 \\
1 \\
\end{array}$ & $\begin{array}{c}26 \\
\pm 0.1 \\
2 \\
\end{array}$ & $\begin{array}{r}11.1 \\
\pm 0.1\end{array}$ & $\begin{array}{r}6.6 \\
\pm 0.1\end{array}$ & $\begin{array}{c}6.8 \\
\pm 0.1 \\
1 \\
\end{array}$ & $\begin{array}{c}8.4 \\
\pm 0 . \\
1 \\
\end{array}$ \\
\hline Tamyia & $\begin{array}{c}8.2 \\
\pm 0.01\end{array}$ & $\begin{array}{r}3.4 \\
\pm 0.1\end{array}$ & $\begin{array}{r}12.2 \\
\pm 0.1\end{array}$ & $\begin{array}{c}4.7 \\
\pm 0 . \\
3\end{array}$ & $\begin{array}{r}10.4 \\
\pm 0.01\end{array}$ & $\begin{array}{c}3.1 \\
\pm 0.01\end{array}$ & $\begin{array}{c}5.1 \\
\pm 0.18\end{array}$ & $\begin{array}{c}1.2 \\
\pm 0.19\end{array}$ & $\begin{array}{c}4.8 \\
\pm 0.1 \\
2 \\
\end{array}$ & $\begin{array}{c}1.8 \\
\pm 0.1 \\
0\end{array}$ & $\begin{array}{c}49.9 \\
\pm 0.1 \\
2 \\
\end{array}$ & $\begin{array}{r}24.9 \\
\pm 0.1\end{array}$ & $\begin{array}{c}7.7 \\
\pm 0.1 \\
1\end{array}$ & $\begin{array}{r}12.1 \\
\pm 0.1\end{array}$ & $\begin{array}{c}6.6 \\
\pm 0.1 \\
1 \\
\end{array}$ & $\begin{array}{r}2.5 \\
\pm 01\end{array}$ \\
\hline
\end{tabular}


Inf: Influent (untreated raw wastewater) and Eff: Effluent (treated wastewater) 


\section{CONCLUSION}

The performance studies on the investigated sewage treatment plants located in ElFayoum Governorate in Egypt conducted from April 2017 to February 2019 reveal that the overall performance achieved by some of the investigated plants is lower than the expected performance and has a negative impact on the ecosystem, as this water leaving from treatment flows into two main drain, the Al-Bats and the Al-Wadi drain, and discharged to Lake Qarun.

From the obtained data of the current investigation we can conclude that, the wastewater treatment stations receive a large amount of drainage reflecting a high percentage of Total Coliform and Fecal Coliform. Furthermore, the high algal content was achieved and nutrients as nitrate, nitrite, ammonia and phosphate were assessed and exhibit in ranges 4.4-104.5, 0.0-8.0, 1.1-43.0 and 1.0-42.1 mg/L respectively. On the other hand, the higher values of TDS and TSS were achieved during summer season. In addition, higher values of DO, BOD and COD are indicators for higher microbial activity.

Consequently, wastewater cannot be used for agricultural activities or drained directly to Lake Karon before treatment, which has many adverse effects on the lake and its lake life. Yet many people in the Fayoum watershed, particularly in rural areas, use these untreated waters, which cause the prevalence of waterborne diseases.

\section{REFERENCE}

Al-Afify, A. D. G.; Othman, A. A. and Ramadan, M. A. (2018). Characterization of chemical and microbiological quality of Nile River surface water at Cairo (Egypt). Rend. Fis. Acc. Lincei https://doi.org/10.1007/s12210-018-0721-8.

Abdel Kawy W, Belal A (2012) Spatial analysis techniques to survey the heavy metals content of the cultivated land in El-Fayoum depression. Egypt Arab J Geosci $5: 1247-1258$

Abdo, M. H. (2004). Environmental studies on the River Nile at Damietta branch region, Egypt. J. Egypt. Acad. Soc. Environ. Develop., (D-Environmental Studies), 5 (2): 85-104.

Abdel Wahaab $R$ (2003) Sustainable development and environmental impact assessment in Egypt: historical assessment. Environmentalist 23:49-70.

Abdel Wahed MSM, Mohamed EA, El-Sayed MI, M'nif A, Sillanpa“a” M (2014) Geochemical modeling of evaporation process in Lake Qarun. Egypt J Afr Earth Sci 97:322-330

APHA (1998) Standard methods for the examination of water and wastewater. American Public Health Association, Washington, DC 
Biodiversity of Holozooplankton community in Lake Qarun, Egypt. Egypt. J. Aquat. Biol. \&Fish., 31(1):230-250.

Bhatnagar, A. and Devi, P. (2013). Water quality guidelines for the management of pond fish culture. Int. J. Environ. Sci., 3(6): 1980 - 1997

Coral, L. A., Zamyadi, A., Barbeau, B., Bassetti, F. J., Lapolli, F. R., Prevost, M. (2013).Oxidation of Microcystis aeruginosa and Anabaena flos-aquae by ozone: Impacts on cell.

integrity and chlorination by-product formation. Water Research, 47(9), 2983-2994.

Edwards, A. C. and Withers, P. J. A. (2008). Transport and delivery of suspended solids, nitrogen and phosphorus from various souries to fresh water in the UK. J. Hydrol., 350: 144 - 153.

Edberg, S. C.; Rice, E. W.; Karlin, R. J. and Allen, M. J. (2000). Escherichia coli: the best biological drinking water indicator for public health protection, Journal of Applied Microbiology 2000, 88, 1068-1168.

Fathi AA, Flower RJ (2005) Water quality and phytoplankton communities in Lake Qarun (Egypt). Aquat Sci 67:350-362

FAO (2003) Users manual for irrigation with treated wastewater. FAO, $\mathrm{TC} / \mathrm{D} / \mathrm{Y} 5009 \mathrm{~F} / 1 / 10.03 / 100$.

Golterman, H. L.; Wisselo, A. G.; Hydrobiologia 1981, 77, 37.

H.L.Golterman, R.S.Clymo (1971) Methods for chemical analysis of freshwaters.IBP Hand book, No., 8

Kagalou, I, Tsimarakis, G. and Paschos, I. (2001). Water chemistry and biology in a shallow lake (Lake Pamvotis-Greece). Present state and perspectives. Global Nest. Int. J., 3: 85-94.

Liu, T.; Wang, H.; Yang, H.; Ma, Y. and Cai, O. (2009). Detection of phosphorus species in sediments of artificial landscape lake in China by fractionation and phosphorus-31 nuclear magnetic resonance pectroscopy. Environ. Pollut., $157: 49-56$.

Mansour SA, Sidky MM (2002) Ecotoxicological Studies. 3. Heavy metals contaminating water and fish from Fayoum Governorate. Egypt Food Chem $78: 15-22$

Mansour SA, Sidky MM (2003) Ecotoxicological Studies. 6. The first comparative study between Lake Qarun and Wadi El-Rayan wetland (Egypt), with respect to contamination of their major components. Food Chem 82:181-189 
Mohammad Mageed, (2005) and Authman and Hossam H.H. Abbas, 2007. Accumulation and Distribution of Copper and Zinc in Both Water and Some Vital Tissues of Two Fish Species (Tilapia zillii and Mugil cephalus) of Lake Qarun, Fayoum Province, Egypt. Pakistan Journal of Biological Sciences, 10: 2106-2122.

Noble, R. T.; Lee, I. M. and Schiff, K. C. (2004). Inactivation of indicator microorganisms from various sources of faecal contamination in sea water and fresh water. J. Appl. Microbiol., 96: 464- 472.

Sivri, N.; Niyazi, K. and Osman, N. V. (2007). Estimation of stream temperature in Firtina Greek (Rize-Turkiye) using artificial neural network model. J. Environ. Biol., 28: 67 - 72.

Sabae, S. Z. and Rabeh, S. A. (2007). Evaluation of the microbial quality of the River Nile waters at Damietta branch, Egypt. Egypt. J. Aqua. Res., 33(1): 301- 311.

Sabae, Z. S. and Mohamed, F. A.S. (2015). Effect of Environmental Pollution on the Health of Tilapia spp. from Lake Qarun. Global Veterinaria 14 (3): 304-328.

WWAP (2009) World Water Development Report 3 "Water in a Changing World". UNESCO, Paris, France 
التقييم الميكروبي والفيزيائي الكيميائي لمحطات الصرف الصحي قبل تصريفها في بحيرة قارون بمحافظة القيوم بمصر.

$$
\begin{aligned}
& \text { محمود محمد السيد'، احمد درويش الجمل'، عمرو فودة'**، احمد علي عطية' } \\
& \text { قسم النبات و الميكروبيولوجي، كلية العلوم بنين، جامعة الازهر ، القاهرة، مصر }
\end{aligned}
$$

Amr_fh83@azhar.edu.eg : البريد الأكتروني للباحث الرئيسي :

(الملخص:

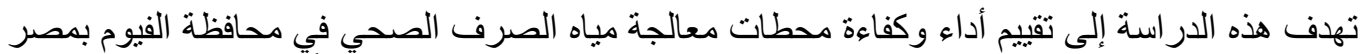

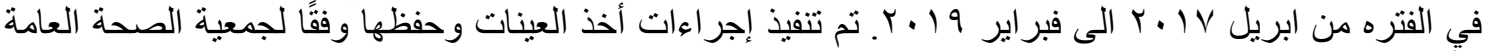

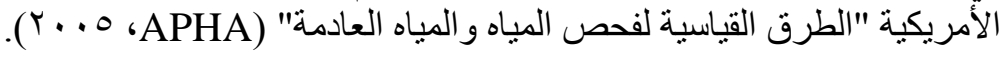

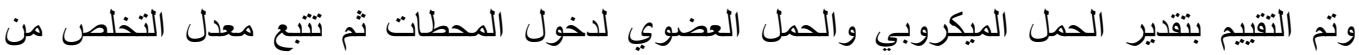

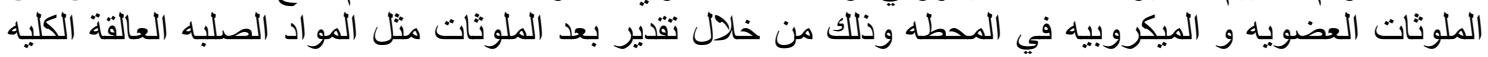

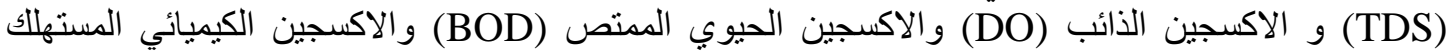
ونيتر ات و الفوسفات الكليه و النيتريت و ولكتيريا القولون الكليه و البر ازيليه و العدد الكلي للطحالب.

وقد أظهرت النتائج أن محطات معالجة مياه الصرف الصحي تتلقى كمية كبيرة من مياه الصرف كالئ كدليل

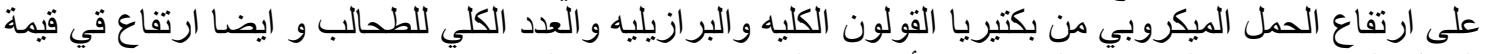

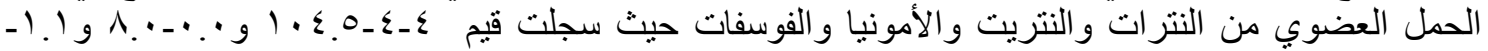

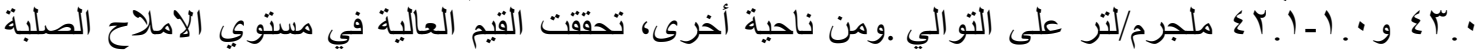

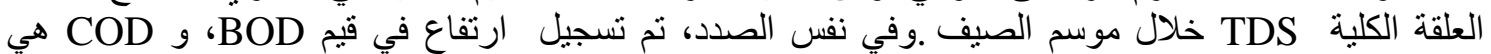
مؤشرات على ارتفاع النشاط الميكروبي.

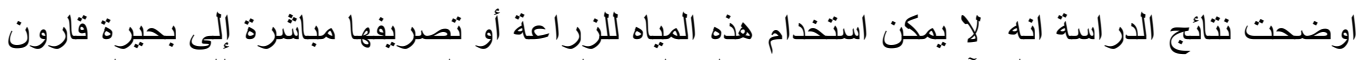

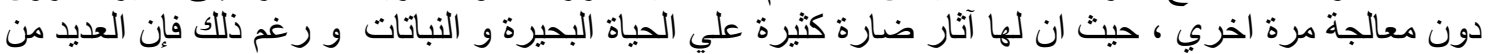
الناس في الفيوم، وخاصة في المناطق الريفية، يستخدمون هذه المياهة المياه غير المعالجة، والتي تتسبب في في انتشار الأمر اض المنقولة عن طريق المياه.

الكلمات المفتاحية : معالجة الصرف الصحي ، بحيرة قارون ، المعالجة البيولوجية ، الحمل الميكروبي ، العد 